Research Article

\title{
Urban Biodiversity in the Light of The Dynamics of Industrial Activities in San-pedro (South-West of the Ivory-Coast)
}

\author{
Bolou Gbitry Abel, Kouamé Kouadio Arnaud, Ogui Chiadon Orphilia Prisca, Nassa Dabié Axel \\ Désiré,
}

\author{
Jean Lorougnon Guédé-Daloa University, Ivory Coast \\ Jean Lorougnon Guédé-Daloa University, Ivory Coast \\ Jean Lorougnon Guédé-Daloa University, Ivory Coast \\ Félix Houphouet-Boigny-Cocody University, Ivoiry Coast,
}

\begin{abstract}
The town of San Pedro, located in south-western Côte d'Ivoire, benefits from numerous natural assets (forest, hydrographic, soil), which contrib ute to its economic and social development and the well-being of its population. This situation particularly contributes to the dynamism of industrial activities to the detriment of biodiversity resources. This study therefore aims to identify the negative effects of the expansion of industrial activities in this city on its biodiversity. The methodological approach used was based on a mixed analysis provided by documentary research and a field survey (interview, questionnaire and direct observation). The processing of the data collected in the field led to the conclusion that the expansion of industrial activities in the town of San Pedro has a strong impact on biodiversity resources. More than $70 \%$ of the economic actors and heads of households interviewed are speechless in the face of this alarming phenomenon in the locality.
\end{abstract}

Key words: Biodiversity, Economic expansion, Industrial activity, San Pedro.

\section{Introduction}

Biodiversity is the living fabric of the planet, covering all natural environments and life forms (French Ministry of Transition and Solidarity, 2018 p.11). Beyond human existence, biodiversity is the essence of present life and the guarantee of future potential, if the means to exercise it remain intact. As can be seen, it is one of the essential dimensions of human existence and the functioning of ecosystems in general, which must be conserved.

However, there is a scientific consensus that the planet's biodiversity is currently in crisis. Indeed, changes and loss of biodiversity are having significant impacts on ecosystem processes (Vanhulst, 2009 p.13). In African cities today, biodiversity resources are limited due to the increased expansion of economic activities. The human species also has an impact on the biosphere due to population growth and the use of natural resources by the population. Thus, the capacity to evolve resources and the sustainability of these resources constitute a survival issue for humans, who are the only species that is aware of, thinks about and shapes its environment (AVIGNON, 2009 p.10). Thus, given the important role that biodiversity plays in maintaining ecosystems and the services that it provides to humans, if there is an imbalance, the survival of the human species is also jeopardised.

The interest in preserving natural resources is essential to maintain the economic model of several African cities. The case of Côte d'Ivoire deserves attention. This country, whose economy is based on agriculture, has a delicate relationship with biodiversity. Indeed, the desire of the public authorities to balance the urban 
structure of Côte d'Ivoire and eventually curb the ultra-attractiveness of Abidjan has led to the creation of other economic centres in the interior of the country. Among these is the city of San Pedro. Faced with this prestige, this coastal city has not escaped the growing coastalization of people and economic activities. This anthropic pressure has contributed to the sprawl of the town outside its original site towards risky and vulnerable areas (Traoré, 2016 p.16). This is not without consequences for its biodiversity. This study aims to identify the adverse effects of the expansion of the city's industrial activities on its biodiversity. The following figure shows the study area in southwestern Côte d'Ivoire.

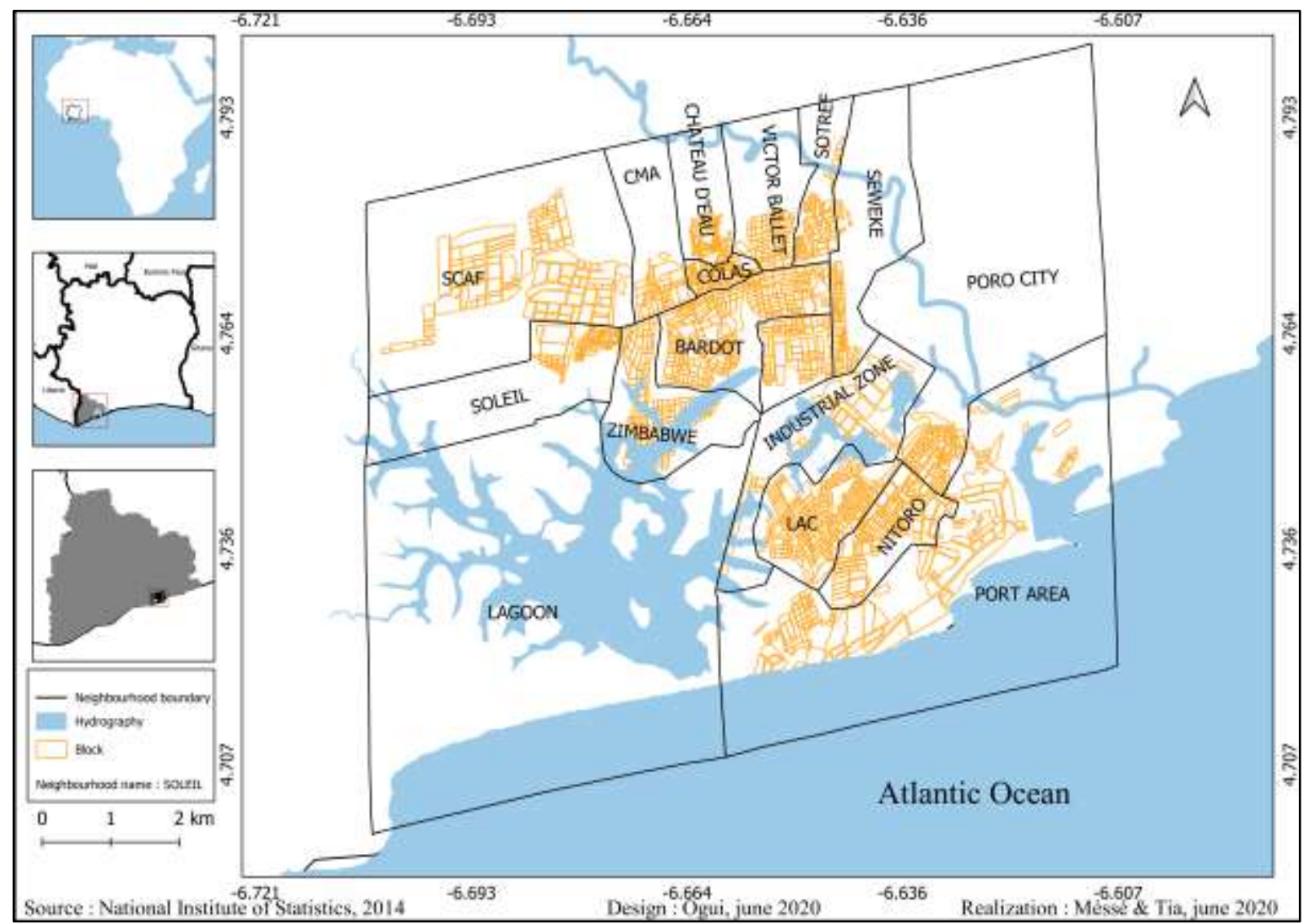

Figure 1: Map of the study area: San Pedro town in 2020

\section{Methods and Materials}

Literature search and field survey were the two types of methods used to collect data. The first was based on a literature review. This was made up of a varied bibliography. Mostly composed of theses, articles and conference reports, this research was carried out in various libraries (IRD, IGT at the University of Cocody, Campus France at the Plateau, UJLOG in Daloa and UFHB in Cocody), as well as scientific research websites (mémoire online, Horizon.documentation.ird.fr. In order to find out the opinion of resource persons on the threat to biodiversity in the urban environment in relation to the city's economic activities, semidirective interviews were held with representatives of public and para-public services and associations. For the questionnaire survey, two population profiles were chosen, namely economic operators working in the secondary sector and households. The choice of industrialists to be surveyed was made with the aim of finding out how they set up, the resources they use for the operation of their activities, their management and the impacts on the urban landscape. Given the large number of industrialists in San Pedro, it seemed necessary to use a non-probabilistic method of reasoned choice. For households, the aim is to collect their opinions on the mode of expansion of industrial activities and the effects of their operation on their living conditions.

- Enumeration of economic operators 
Bolou Gbitry Abel et. al/ Urban Biodiversity in the Light of The Dynamics of Industrial Activities in San-pedro (SouthWest of the Ivory-Coast)

The choice of these different actors was made according to the types of industries. There are two categories of industry in San Pedro: agro-industry and non-agricultural industry, both of which total 43 industrial units. The questionnaire was administered to two types of actors (a manager and a worker) per type of industry surveyed. To do this, the non-probabilistic snowball method was used, which consisted of interviewing one actor in a factory who in turn indicated another actor with the same activity profile. On the whole, those that were accessible were interviewed. In this way, a total of 50 industrial actors were interviewed in 25 industrial units (Table I).

Table I: Number of economic operators surveyed in 2020

\begin{tabular}{|c|c|c|c|c|}
\hline Categories & $\begin{array}{l}\text { Type of } \\
\text { industry }\end{array}$ & Activity(ies) conducted & $\begin{array}{c}\text { Products } \\
\text { used }\end{array}$ & Number \\
\hline \multirow{6}{*}{ Agro-industry } & Cocoa industry & $\begin{array}{l}\text { Machining, processing, } \\
\text { packaging }\end{array}$ & Cocoa & 20 \\
\hline & Coffee industry & $\begin{array}{l}\text { Machining, processing, } \\
\text { packaging }\end{array}$ & Coffee & 4 \\
\hline & Wood industry & Joinery, veneer, sawing & Wood & 12 \\
\hline & Rubber industry & $\begin{array}{l}\text { Production of granulated, } \\
\text { compact rubber }\end{array}$ & Hevea & 4 \\
\hline & Oilseeds & Cashew kernel production & $\begin{array}{l}\text { Cashew } \\
\text { nuts }\end{array}$ & 2 \\
\hline & Milling & Production of bakery flour & Wheat & 2 \\
\hline $\begin{array}{c}\text { Non- } \\
\text { agricultural } \\
\text { industry }\end{array}$ & $\begin{array}{l}\text { - Cement } \\
\text {-Tannery } \\
\text { - Concrete plant }\end{array}$ & $\begin{array}{l}\text { Manufacture of concrete, } \\
\text { cement, leather materials }\end{array}$ & $\begin{array}{l}\text { Leather, } \\
\text { sand, } \\
\text { gravel }\end{array}$ & 6 \\
\hline \multicolumn{4}{|c|}{ Total } & 50 \\
\hline
\end{tabular}

Source : Our surveys, February 2020

- Enumeration of households to be surveyed

The enumeration of households to be surveyed was carried out with a focus on neighbourhoods with many economic activities. The table below shows the different neighbourhoods and the number of households found within them.

Table II: Summary of the number of heads of households surveyed

\begin{tabular}{|l|l|}
\hline NEIGHBOURHOODS & NUMBER OF HEADS OF \\
& HOUSEHOLD \\
\hline LAC OR SONOUKO & 69 \\
\hline PORT AREA or RADE & 32 \\
\hline INDUSTRIAL ZONE & 104 \\
\hline PORO-CITE & 32 \\
\hline SOTREF Total & $\mathbf{4 1 1}$ \\
\hline \multicolumn{2}{|c|}{} \\
\hline
\end{tabular}

Source: Our surveys, February 2020 
Bolou Gbitry Abel et. al/ Urban Biodiversity in the Light of The Dynamics of Industrial Activities in San-pedro (SouthWest of the Ivory-Coast)

In total, $10 \%$ of the 4107 households in the city's five economic districts were surveyed using this empirical method used by the social sciences (Beaud and Webber, 2010, cited by Traoré (2016, p. 83). In addition to the establishment of this sampling frame, field observation was carried out during the investigations. The data collected in the field was processed using a pivot table in Excel.

\section{Results \\ Natural resources: the basis for economic expansion \\ Inventory of biodiversity resources in the town of San Pedro}

The town of San Pedro is rich in natural resources in terms of water, land, geology and soil. These resources make the town an area with special characteristics. For 250 kilometres, the ocean borders the south of the town and has been the country's second largest port since 1970. The San Pedro River, which is 150 kilometres long, has a catchment area of about 3380 kilometres and an average flow rate of about $22.8 \mathrm{~m}^{3}$. It flows through the classified forest of Rapide Grah towards the south of the city. The river is the main source of water for the city's water tower. The Digboue lagoon covers about $4 \mathrm{~km}^{2}$ and is isolated from the sea by a barrier beach. With a catchment area of about $170 \mathrm{~km}^{2}$, it flows to the west of the town. Traditional fishing and other informal economic activities take place in this resource. The lake of San-Pedro is an artificial body of water of $1.12 \mathrm{~km}^{2}$ wedged between the districts, Cité (Poro 1 and 2), Sonouko and the industrial zone. This resource was created by the construction of an agro-hydro dam on the San Pedro River. Originally, it was intended to serve as an outlet for drainage water, domestic and industrial wastewater, which is not the case on the ground. The marshes in the city are waterlogged on a daily basis. They are located mainly in the marshy areas and low-lying areas almost throughout the city.

On the other hand, the alluvial (hydromorphic) soils located in the south of the city are more prone to flooding, as they are less impermeable. Indeed, $70 \%$ of the industrial actors use sand from these soils for construction and other purposes. Similarly, plant species such as samba, iroko, sipo and bété wood are favoured by $65 \%$ of the industrial actors interviewed, and animal species (wild boar, warthogs, elephants) are of interest to $1 / 3$ of the city's tourists. These different resources have led to the installation of various industrial activities. This inventory shows the diversity and density of natural resources in the city. Each resource has its own characteristics through its distribution. Figure 2 shows the various water resources that drain the locality. 
Bolou Gbitry Abel et. al/ Urban Biodiversity in the Light of The Dynamics of Industrial Activities in San-pedro (SouthWest of the Ivory-Coast)

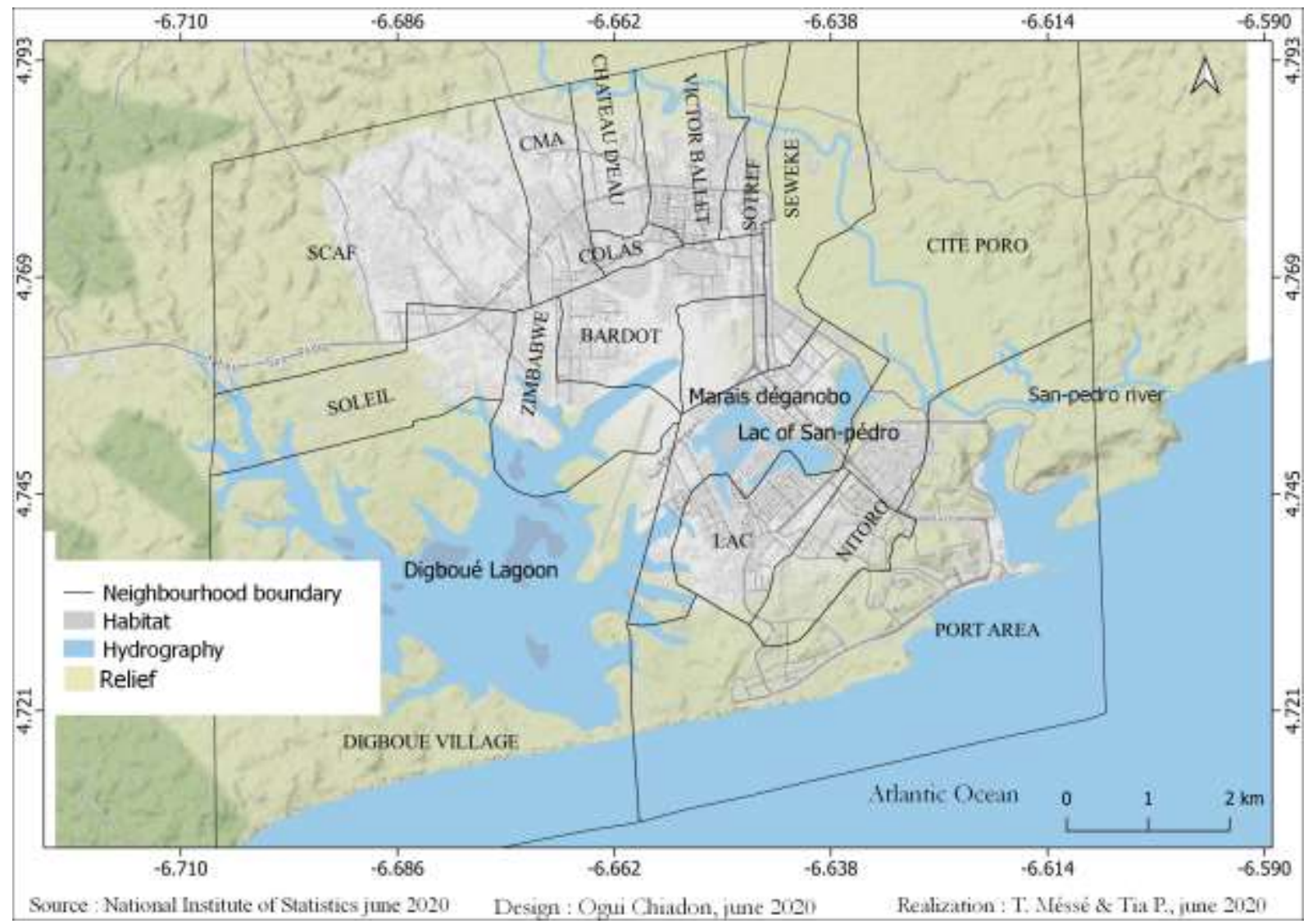

Figure 2: Water resources within the town of San Pedro

Water resources are the main biodiversity resources of the city

Emergence of a diversity of industrial activities in San Pedro

The richness of the natural environment is a source of attraction for human activities. Thus, industries make up $27 \%$ of all the city's equipment and infrastructure. The following table shows the share of each type of industry in San Pedro.

Table III: Proportion of each type of industry in San Pedro

\begin{tabular}{|c|l|l|}
\hline Type of industry & Number & Proportion (\%) \\
\hline Agro-industry & 38 & 88 \\
\hline Non-agricultural industry & 5 & 12 \\
\hline Total & $\mathbf{4 3}$ & $\mathbf{1 0 0}$ \\
\hline
\end{tabular}

Source : San Pedro Directorate of Industry, 2015 and personal survey, February 2020

San Pedro has several industrial units concentrated mainly around agro-industry, and non-agricultural units contributing to about $65 \%$ of the local domestic product (San Pedro Industry Directorate, 2015). The locality has enormous economic potential, which makes it a pole of attraction for many national and international economic operators, as well as for populations of diverse origins. There are several reasons for this interest in this locality. Among these, the existence of a port has favoured the establishment of agro-industrial units, processing (cocoa, coffee, oil palm), wood industries, oilseed units, milling and other non-agricultural industries.

In general, San Pedro's industries are dominated by agro-industry (88\%) against (12\%) non-agricultural units. In the cocoa sector, there are companies that process and package cocoa beans, such as UNICO, SACO, CHOCO IVOIRE, etc., which produce chocolate products for domestic consumption and for export. 
Bolou Gbitry Abel et. al/ Urban Biodiversity in the Light of The Dynamics of Industrial Activities in San-pedro (SouthWest of the Ivory-Coast)

For wood, there are 14 units composed of veneer, sawing and carpentry industries. As regards oilseeds, there is only one unit, the company (SIVECCO), specialising in the production of cashew kernels ; and in milling, there is the Grand Moulin, which specialises in the manufacture of flour. The last category of industries includes non-agricultural units that represent only $12 \%$ of all industries in San Pedro. These are specialised in the manufacture of cement, ready-mixed concrete and industrial mechanics. Figure 3 shows the location of economic activities within the town of San Pedro.

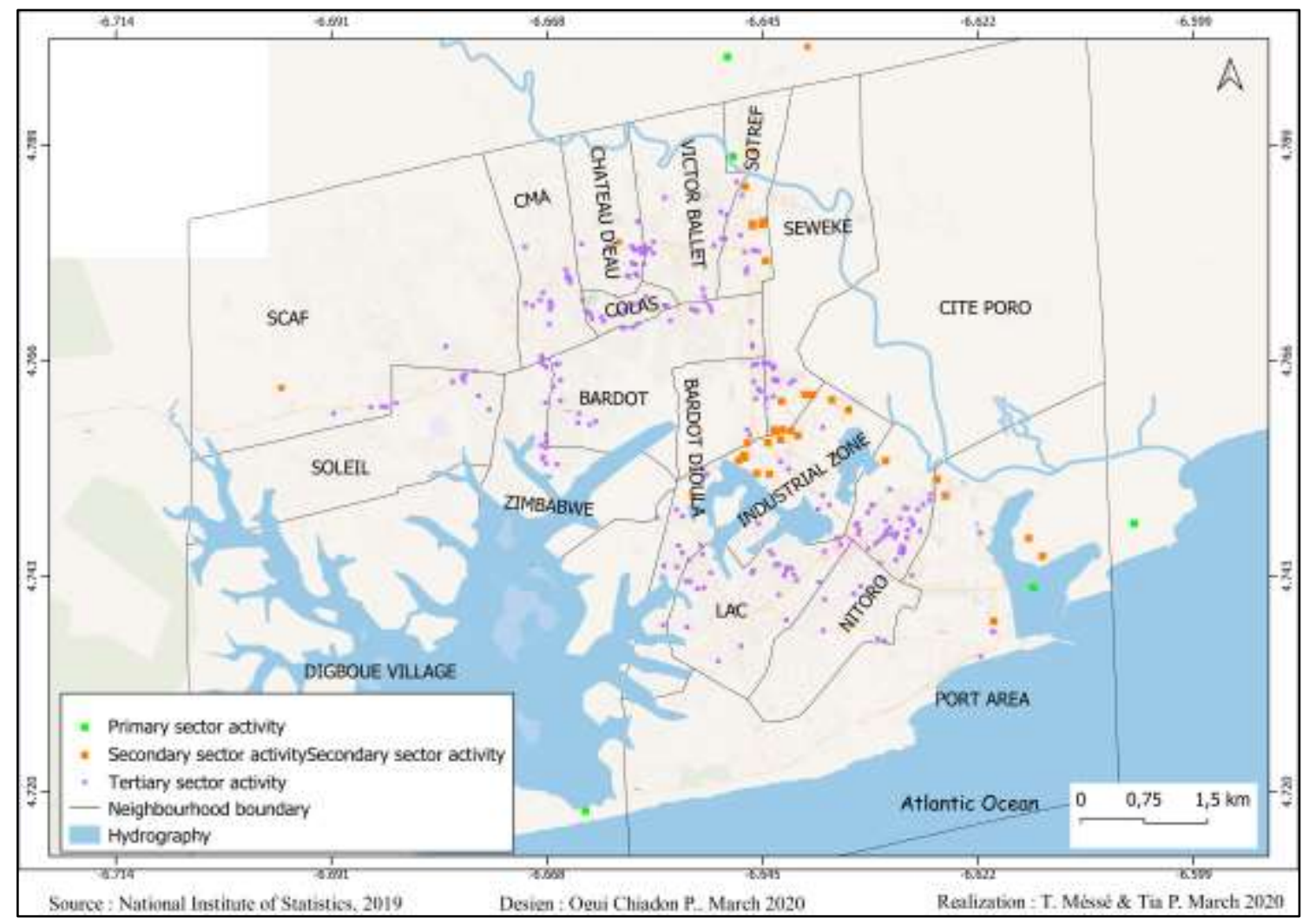

Figure 3 : Distribution of economic activities in San Pedro

The spatial distribution of economic activities in San Pedro clearly indicates that the activities of the tertiary sector are located in all the districts of the city, with a strong presence in the southern and northern parts. The activities of the secondary sector are concentrated in the southern part of the city. Primary sector activities are located in the north. Overall, the secondary sector occupies $43 \%$ of the urban space of San Pedro. The secondary sector is the one that destroys the most biodiversity in this city with $52 \%$ of responsibility, followed by the tertiary sector with $20 \%$ and the primary sector with $18 \%$.

\section{Functional practices of industrial activities affecting biodiversity}

Socio-demographic and economic profile of actors responsible for the degradation of natural resources

The secondary sector is dominated by a large foreign population, either allochthonous or non-indigenous (see following table).

Table IV: Socio-demographic profile of the formal private workforce

\begin{tabular}{|c|c|c|c|}
\hline $\begin{array}{l}\text { Origine sociale de } \\
\text { l'acteur }\end{array}$ & Native & Allochthonous & Allogeneous \\
\hline Industries and sawmills & $1 \%$ & $40 \%$ & $59 \%$ \\
\hline
\end{tabular}


Bolou Gbitry Abel et. al/ Urban Biodiversity in the Light of The Dynamics of Industrial Activities in San-pedro (SouthWest of the Ivory-Coast)

Source: Personal survey, February 2019

This table shows that non-natives are more involved in industrial activities, with a proportion of 59\%, against $40 \%$ of non-natives and $1 \%$ of natives. The industrial activity is carried out by a foreign population, the majority of which is Lebanese, with a proportion of $60 \%$, against $31 \%$ of Ivorians and $9 \%$ for other nationalities (Malians, Mauritanians). However, it should be noted that the Lebanese are involved in both trade and industry. The predominance of actors from this nation can be explained by their very old integration (colonial period) and their perfect knowledge of the business world in Côte d'Ivoire.

\section{Effects of industrial activities on the degradation of natural areas}

The industrial sector is the main cause of air pollution in San Pedro. This is mainly due to the fumes from the incineration of waste and boilers from the various industrial units that they produce in the city. Of the 25 industrial units surveyed, 19 use furnaces and boilers within their structure. The figure 4 shows the proportion of these industrial units by sub-sector of activity.

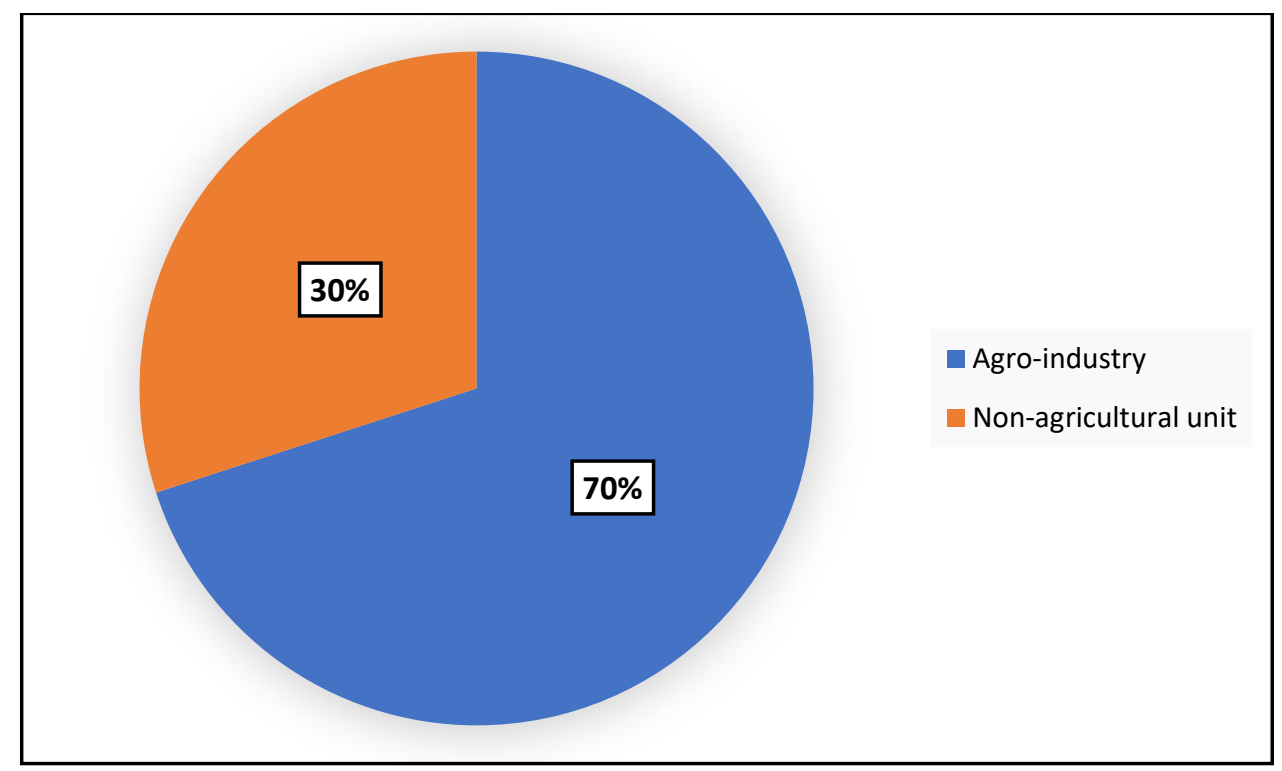

Source : Our surveys, February 2020

Figure 4 : Proportion of boiler and furnace users by type of industrial unit

This figure shows that agro-industry is the main air polluting activity in San Pedro because $70 \%$ of the operators in this sub-sector use ovens and boilers. Indeed, the chimneys installed by the industrialists in order to pass the smoke are not high and constitute a danger for the surrounding environment. The main pollutants emitted by this system are suspended particles (the finest dust is mainly emitted by the cocoa and wood industries), carbon monoxide (CO), volatile organic compounds (VOCs), ozone (a secondary pollutant from hydrocarbons and nitrogen dioxide). These various pollutants constitute a major threat to the population and to the actors. This pollution is denounced by $69 \%$ of households living near these units, which are dominated by agro-industries. Figure 5 highlights the extent of the different forms of degradation according to the areas where households live. 
Bolou Gbitry Abel et. al/ Urban Biodiversity in the Light of The Dynamics of Industrial Activities in San-pedro (SouthWest of the Ivory-Coast)

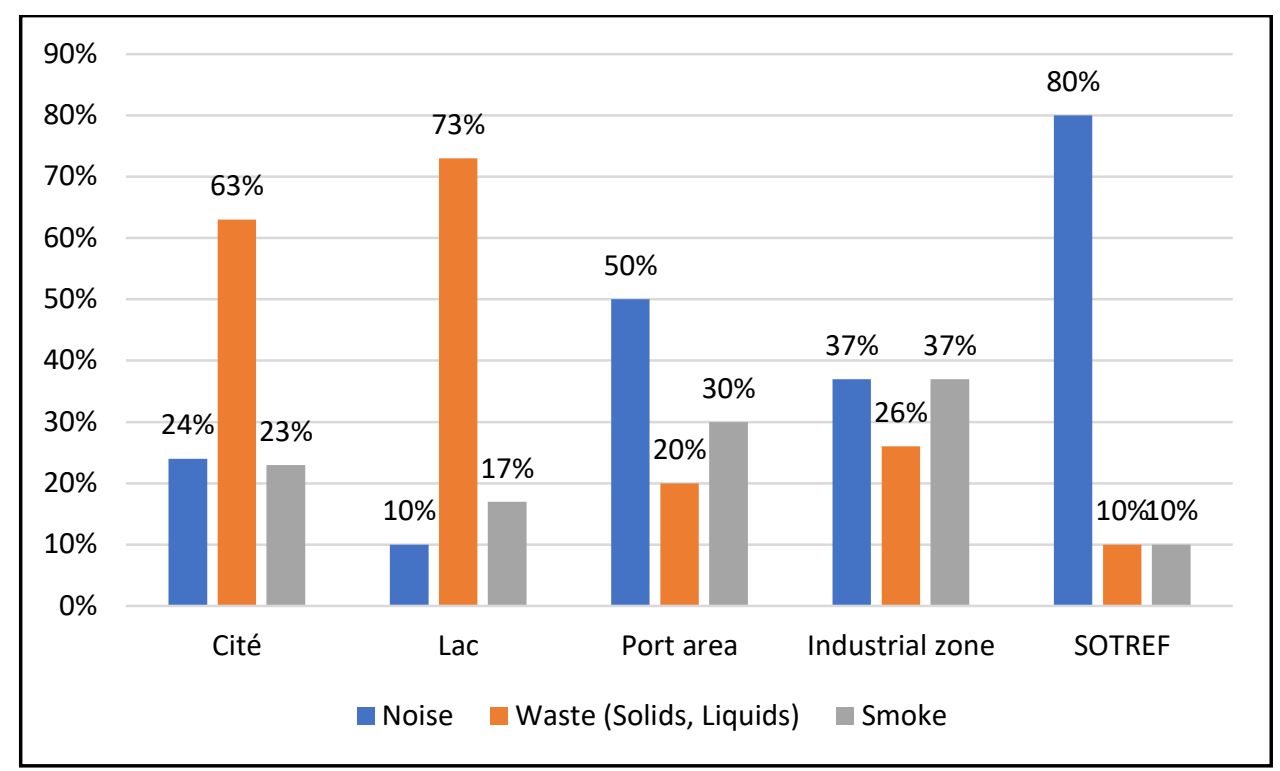

Source : Our surveys, February 2020

Figure 5: Type of degradation caused by economic operators by neighbourhood according to households

Industrial waste, noise emitted by industries and smoke from them are the forms of pollution mainly blamed by the surrounding households. The Lac and Cité neighbourhoods are home to both household and industrial waste, with proportions of $73 \%$ and $63 \%$ respectively. Noise pollution is more important in the SOTREF, port zone and industrial zone neighbourhoods with proportions of $80 \%, 50 \%$ and $37 \%$ respectively. Atmospheric pollution (smoke, dust) is more significant in the industrial zone and the port zone with $37 \%$ and 30\% respectively in each of these neighbourhoods. The following table summarises the types of industry and their form of degradation.

Table V : Form of degradation according to the resources used and their origin

\begin{tabular}{|c|c|c|c|}
\hline $\begin{array}{l}\text { TYPE OF } \\
\text { INDUSTRY }\end{array}$ & $\begin{array}{l}\text { RESOURCE } \\
\text { S USED }\end{array}$ & SOURCE OF RESOURCES & $\begin{array}{c}\text { FORMS OF } \\
\text { DEGRADATION }\end{array}$ \\
\hline Agribusiness & $\begin{array}{l}\text {-cocoa } \\
\text {-coffee }\end{array}$ & $\begin{array}{l}-85 \% \text { from outside the city } \\
\text { (Soubré, Rapide-Grah) } \\
-15 \% \text { from surrounding camps }\end{array}$ & $\begin{array}{l}\text { - Air pollution } \\
\text { - Pollution of the } \\
\text { living environment } \\
\text { - Water pollution }\end{array}$ \\
\hline Wood industry & Wood & $\begin{array}{l}-85 \% \text { from outside the city } \\
\text { (Soubré, Rapide-Grah) } \\
-15 \% \text { from surrounding camps }\end{array}$ & $\begin{array}{l}\text { - Air pollution } \\
\text { - Pollution of the } \\
\text { living environment } \\
\text { - Water pollution }\end{array}$ \\
\hline Wheat milling & wheat & $\begin{array}{l}\text {-outside the city (mostly from } \\
\text { the north of the country) } \\
\text {-Outside the country (Egypt, } \\
\text { Morocco, Algeria) }\end{array}$ & $\begin{array}{l}\text { - Air pollution } \\
\text { - Pollution of the } \\
\text { living environment }\end{array}$ \\
\hline Oilseeds & Cashew nuts & Out of town & $\begin{array}{l}\text { - Air pollution } \\
\text { - Pollution of the } \\
\text { living environment } \\
\text { - Water pollution }\end{array}$ \\
\hline $\begin{array}{l}\text { Chemical } \\
\text { industry (cement } \\
\text { factory) }\end{array}$ & $\begin{array}{l}\text {-Sand } \\
\text {-Gravel } \\
\text {-Water } \\
\text {-Clay }\end{array}$ & $\begin{array}{l}\text {-Within the city } \\
\text { - Outside the city }\end{array}$ & $\begin{array}{l}\text {-Soil pollution } \\
\text {-Pollution of the } \\
\text { living environment } \\
\text {-Air pollution }\end{array}$ \\
\hline
\end{tabular}

Source : Our surveys, February 2020 
Bolou Gbitry Abel et. al/ Urban Biodiversity in the Light of The Dynamics of Industrial Activities in San-pedro (SouthWest of the Ivory-Coast)

\section{Biodiversity loss: between reduced economic activity and various threats}

\section{Closure of industrial units}

With the scarcity of natural resources used as raw materials for the operation of industrial units, many have closed or are experiencing difficulties in obtaining raw materials (see following figure 6).

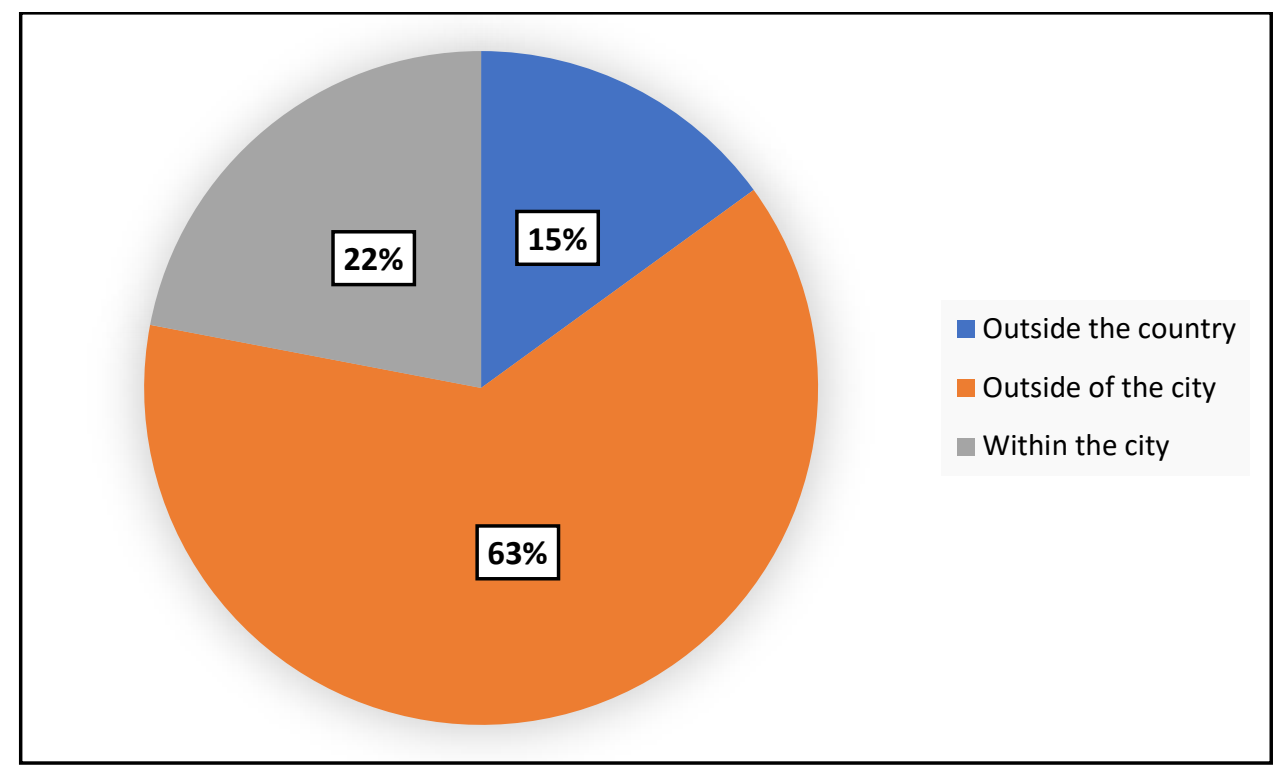

Source : Our surveys, February 2020

Figure 6 : Origin of resources used by economic actors

The figure 6 shows that $63 \%$ of economic operators have been drawing their resources from outside the city, or even outside the region, for the past 5 years due to the drop in local raw materials. This reality has led to the closure of $1 / 3$ of the industries surveyed in the city due to lack of raw materials since 2015 .

\section{Irrational use of water resources and disruption of the drinking water supply}

During the survey, $90 \%$ of the population denounced a decrease in the supply of drinking water over the last 10 years in the town of San Pedro. Indeed, the river resource is irrationally used by private structures installed upstream. According to a SODECI report, the river's flow rate has fallen from $22.8 \mathrm{~m} 3$ to $15.22 \mathrm{~m} 3$. This explains the problem of sharing drinking water throughout the city over the past 10 years (Figure 7).

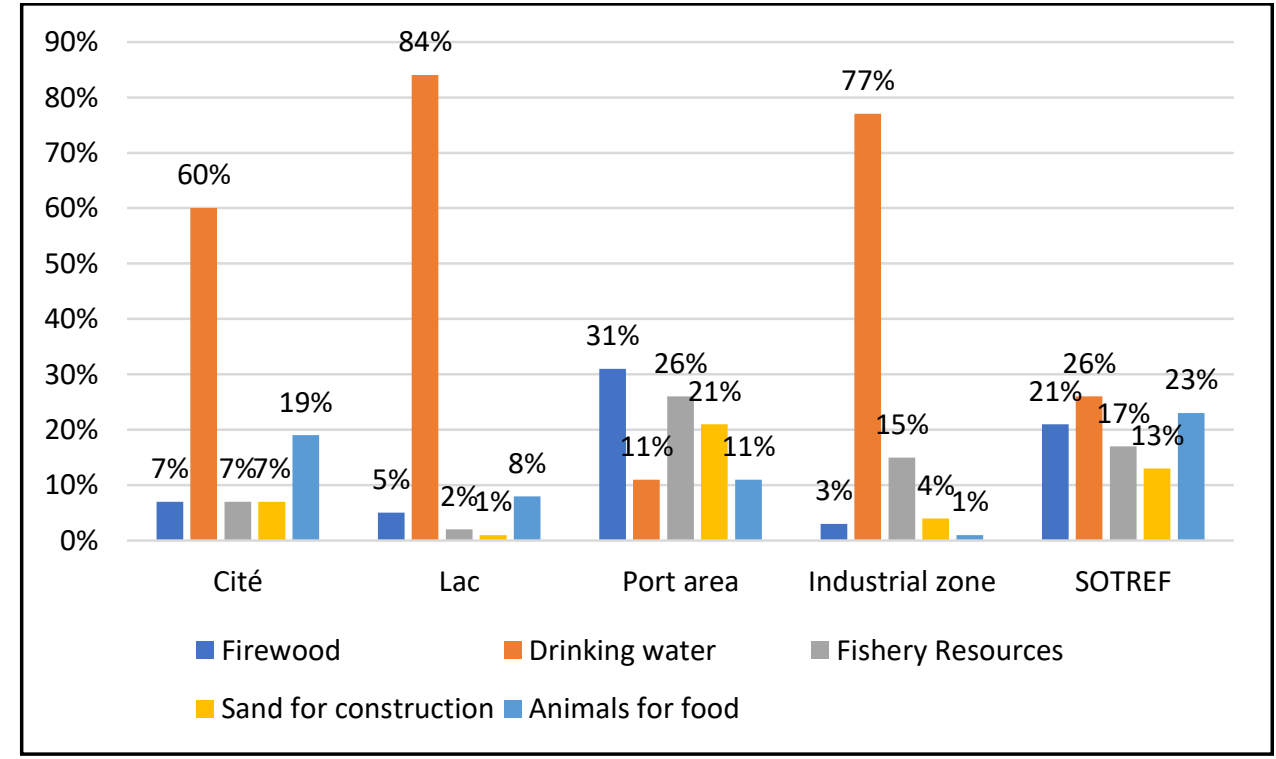

Source : Our surveys, February 2020 
Bolou Gbitry Abel et. al/ Urban Biodiversity in the Light of The Dynamics of Industrial Activities in San-pedro (SouthWest of the Ivory-Coast)

Figure 7 : Declining natural resources over the last 10 years

This diagram indicates that over the past 10 years, households have felt a decline in all natural resources in San Pedro. But water resources are the most affected. Households denounce this particularly in the Lake, Industrial Zone and Cité neighbourhoods, with proportions of $84 \%, 77 \%$ and $60 \%$ respectively.

Expansion of spaces dedicated to the economy to the detriment of vegetation cover

In four decades, San Pedro, the city with an economic vocation with the installation of the port in 1970 and the industrial zone, has experienced considerable sprawl with the influx of foreign populations in search of employment. From 335 hectares in 1975, the surface area of the city had grown to approximately 3767 hectares in 1998. Today, the city covers an area of 6120 hectares (Figure 8).

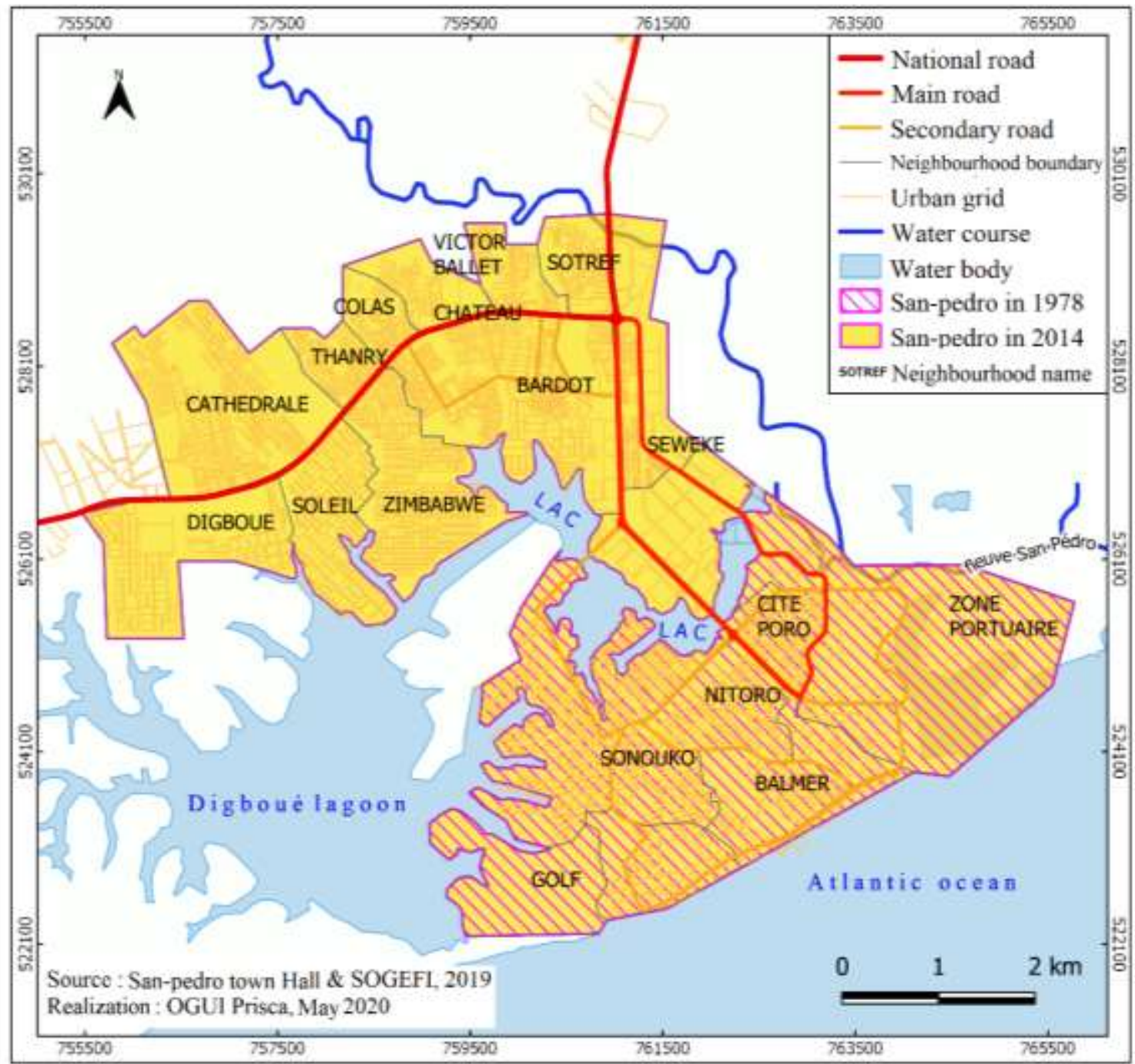

Figure 8 : San Pedro from its inception from 1978-2014

The city has gone from 6 planned districts in 1978 to 19 districts in 2020. This attraction of populations for port and industrial activities is likely to intensify at the expense of hectares of vegetation.

\section{Exposure of households and economic operators to diseases}

At the end of the survey, $95 \%$ of households and $65 \%$ of economic operators denounced the presence of heavy dust in the city. According to the Regional Health Director of San Pedro, "Dust is a factor in the presence of meningitis. The lack of vegetation cover to store dust particles is an element for the evolution of 
Bolou Gbitry Abel et. al/ Urban Biodiversity in the Light of The Dynamics of Industrial Activities in San-pedro (SouthWest of the Ivory-Coast)

this disease within households, which suffer enormous consequences. " The figure 9 below highlights the main diseases that frequently affect the households surveyed.

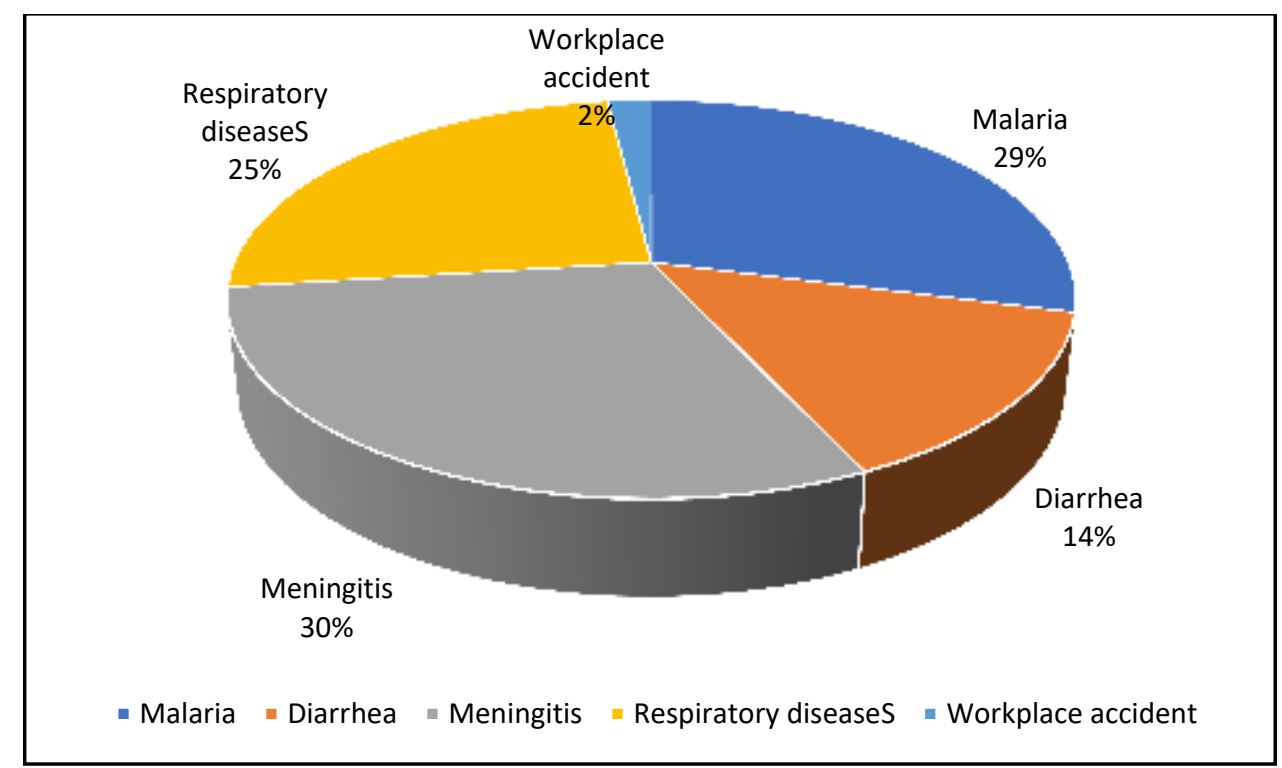

Source : Our surveys, February 2020

Figure 9: Type of disease contracted in households and by economic operators

The figure 9 shows that malaria accounts for $29 \%$, respiratory diseases for $25 \%$, diarrhoea for $14 \%$, meningitis for $30 \%$, and work-related accidents for only $2 \%$. These rates show that meningitis is a widespread disease in San Pedro. As the Regional Director of Health for the South-West pointed out, this disease mainly affects children under 15 and the elderly. It causes the death of one in ten (1/10) people and many survivors are disabled within the town.

\section{Discussion}

The present study revealed the presence of a large number of faunal, floristic, hydrographic and pedological resources in the locality of san pedro, a town on the ivorian coast. this plurality of resources has led to the development of several economic activities. it is in this context that anoh (2013, pp.40-41) states on the one hand that the coastline benefits from several natural assets that contribute to its densification and modification due to the development of economic activities. similarly, n'guessan (2013, pp.127-128), argues that from the 1970s onwards, both non-native and native populations rushed to attack the city, leading to a rapid and spontaneous urbanisation. In the same vein, lefebvre (2011, p.3) specifies that at the heart of the great flows of people, capital and goods, the coastlines have been increasingly developed to the point where they are now of strategic importance. these resources are then factors in the installation of numerous economic activities in this ivorian locality.

The destruction of biodiversity is caused by the phenomenon of littoralisation at work in san pedro. The results of the research show that the secondary sector is the one that destroys the most biodiversity in this town with $52 \%$ of responsibility, followed by the tertiary sector with $20 \%$ and the primary sector with $18 \%$. these results are similar to those of tuo (2016, p1-25), which reveal that the secondary sector has a large share in the destruction of biodiversity. this degradation is accentuated by the widespread establishment of industrial activities in the vicinity of city districts and by the increased use of raw materials. this is why duffourc (2009, p.25-26 and p.32-37) states that the presence of industry in a city is certainly a source of job creation but also of environmental destruction. In this respect, pinchemel and pinchemel (1997, p. 340) have pointed out a few years ago that these effects result from excessive cumulative human practices. For their part, burgel and grondeau (2020, p. 241) emphasise that the polluting nature of industry in the urban 
environment results from the density of land use, which entails risks of degradation in terms of the atmosphere, water, transport and the exposure of the population to dangers.

In san pedro, this destruction can be seen in certain indicators and problems mentioned by households. The consequences of this deterioration are characterised by the occurrence of diseases including malaria (29\%), respiratory diseases $(25 \%)$, diarrhoea $(14 \%)$ and meningitis $(30 \%)$. The destruction of biodiversity has consequences for households. The results of coulibaly and al's work $(2014, \mathrm{p} .8)$ highlight, the recurrence of diseases contracted by populations due to environmental degradation in urban centres. For him, human activities in urban areas impact the environment with the corollary of the degradation of the health of populations. torterotot (1993, pp.304 and 350) in his work, also states that by submerging land, floods lead to harmful effects on the natural environment as well as on human societies, so such is the case of the town of san pedro which presents enormous problems in terms of flooding of neighbourhoods. this damage has resulted in the loss of human life and the destruction of homes, leaving households homeless. But it is not only households that suffer the effects of flooding. Animal and plant species in the water environment are also affected, as floods play a sometimes harmful and irreplaceable role in both the biological process and the water cycle, making these species vulnerable.

In addition to the diseases, the survey showed that $1 / 3$ of the industries in the town of san pedro have closed due to lack of raw materials. The abusive exploitation of the flora has led to a shortage of wood for the operation of industries and sawmills in the town of san pedro. yobo and nassa, (2018, p.91 and 101) also explain that deforestation is the main source of biodiversity degradation and the primary consequence of this practice is the lack of raw materials, particularly wood. this practice leads to the slowing down or even the closure of certain industries operating in this sector.

faced with these consequences, it is necessary to challenge the actors involved in this deterioration and to raise their awareness of better management of natural resources, as the preservation of biodiversity makes a major contribution to the economy (ministry of the environment, energy and the sea in charge of international climate relations of the french republic, 2016, p.9).

\section{Conclusion}

At the end of this study, it is noted that there is a diversity of biodiversity resources in San Pedro. This diversity of resources has led to the installation of numerous industrial activities, with the corollary of strong pressure on them by the various stakeholders. The resulting impacts are perceptible both on the urban landscape and on the health of the population. Around the economic dynamism of the city, the extent of this phenomenon is becoming a concern for all. It is therefore important to revitalise urban policies and development methods with a view to better preserving natural resources in San Pedro.

\section{References}

1. Anoh Kouassi Paul and POTTIER Patrick, dirs., 2008 - Geography of the coast of Ivory Coast: elements of reflection for an integrated management policy. CNRS-LETG UMR 6554 and IGT : Nantes - Abidjan, 325 p. / Book reviews prepared by Anoh K.P . (2010) ; pages 485-489. https://journals.openedition.org/com/6097.

2. AVIGNON DE VAUCLUSE (2009), Biodiversity and Territory Biennial, Report, preparatory seminar, pages 88. https://www.volubilis.org/wp-content/uploads/2017/01/2009-actess\%C3\%A9minaire-biodiversit\%C3\%A9.pdf

3. Burgel G.C and A.Grondeau (2020), Urban Geography, Paris, Vanves, Hachette coll. "HU Géography", 288 pages. http://journals.openedition.org/cybergeo/29121 ; DOI : https://doi.org/10.4000/cybergeo.29121

4. Coulibaly M., Tuo P. and D.F Ake-Awomon (2018), Insalubrity and infectious diseases in the precarious neighborhoods of Yopougon Gesco-attie : case of Judé, Mondon and Ayakro (Abidjan, 
Bolou Gbitry Abel et. al/ Urban Biodiversity in the Light of The Dynamics of Industrial Activities in San-pedro (SouthWest of the Ivory-Coast)

Ivory Coast), Space, Territories, Societies and Health Review, "[Online] 2018, posted 08 July 2018, accessed 2021-04-27 16:57:19, URL: https://www.retssa-ci.com/index.php?page=detail\&k = 18 .

5. Duffourc V. (2009), Planning and biodiversity: biological traits and environmental factors associated with the organization of animal and plant communities along a rural-urban gradient, research dissertation, University of Réunion, 84 pages. https://agritrop.cirad.fr/554048/1/document_554048.pdf.

6. Lefebre C. (2011), Integrated coastal and marine management : new perspectives, Vertigo, the electronic journal in environmental sciences, accessed on 7 November 2019 URL : http//Vertigio.revues.org/10985

7. MINISTRY OF THE ENVIRONMENT, ENERGY AND THE SEA IN CHARGE OF INTERNATIONAL RELATIONS ON THE CLIMATE OF THE FRENCH REPUBLIC, (2016), Biodiversity, an opportunity for economic development and job creation, Report, 90 pages

8. MINISTRY OF TRANSITION AND FRENCH SOLIDARITY (2008), National service of regulatory assistance CLP, consulted on August 22, $2019 ; 12$ pages.

9. N'Guessan A.A.B. (2013), "Port and Land Use Planning in Ivory Coast: Assessment and Perspectives from San Pedro ", Review of Geography of the University of Ouagadougou, number 002, Volume 1, pages 123-140.

10. Pinchemel PH. and G. Pinchemel (1997), The face of the earth, Paris, Armand Colin, 520 p.

11. Torterotot J.PH (1993), The cost of flood damage : estimation and analysis of uncertainties, Paris, ENPC PhD Thesis, Volume 2, 354 pages.

12. Tuo P., Coulibaly M., D. F. Ake Epse Awomon, A.T. Tamboura, K.P. Anoh (2016), "Household waste, wastewater and population health in the city of Daloa (Center-West of Ivory Coast) ", Journal of Geography, Regional Planning and Development of the South (REGARDSUDS), Institute of Tropical Geography-University Félix Houphouët Boigny (Abidjan-Ivory Coast), n ${ }^{\circ}$ 2, pages $195-$ 213.

13. Traore K.M. (2016), analysis of the vulnerabilities of the Coastal coast of San Pedro (South-West of Ivory Coast), environment and society, PhD Thesis , Félix Houphouët Boigny University of Cocody Abidjan, 354 pages.

14. Vanhulst J. (2009), Threats and perspectives for the preservation of biodiversity in the Juan Fernandez archipelago (Chile), University of Brussels, Master in environmental management sciences IGEAT-ULB, 129 pages.

15. Yobo J. and D.D.A. Nassa (2018), "Mining, a factor in the recession of agricultural activity in Hiré Watta in Ivory Coast", Review GEOTROPE, ${ }^{\circ}{ }^{\circ}$, 2018, pp 91-101. 